\title{
Magic Finger Teaching Method in Learning Multiplication Facts among Deaf Students
}

\author{
Liong Kon Thai ${ }^{1} \&$ Mohd. Hanafi Mohd Yasin ${ }^{1}$ \\ ${ }^{1}$ Faculty of Education, The National University of Malaysia, Malaysia \\ Correspondence: Liong Kon Thai, Faculty of Education, The National University of Malaysia, Malaysia. Tel: \\ 60-19-916-8218. E-mail: ktliong@yahoo.com
}

Received: March 18, 2016

Accepted: April 1, 2016

Online Published: April 21, 2016

doi:10.5539/jel.v5n3p40

URL: http://dx.doi.org/10.5539/jel.v5n3p40

\begin{abstract}
Deaf students face problems in mastering multiplication facts. This study aims to identify the effectiveness of Magic Finger Teaching Method (MFTM) and students' perception towards MFTM. The research employs a quasi experimental with non-equivalent pre-test and post-test control group design. Pre-test, post-test and questionnaires were used. As many as 70 deaf students from three special education primary schools in Selangor and Federal Territory were gathered as research respondent. Data were analyzed by using descriptive and inferential statistics of t-test. Findings from the t-test analysis showed that MFTM has a significant effect on multiplication facts achievement among deaf students whereas conventional teaching method does not given a significant effect on multiplication facts achievement among them. The findings from questionnaires found that the deaf students have high level of perception towards MFTM in the dimensions of interest, self-confidence, persistence and motivation in learning multiplication facts. The findings serves as an implication towards students, parents, teachers, Special Education Division and Malaysia Education Ministry in terms of awareness, involvement, planning and implementation in the context of diversifying of multiplication facts teaching method, and the suitability of supporting materials in teaching and learning multiplication facts.
\end{abstract}

Keywords: deaf, Magic Finger Teaching Method (MFTM), multiplication facts learning

\section{Introduction}

Mathematics is important not only academically but it is also one of the criteria that will be considered in application of the career (Stewart \& Kluwin, 2001) and our daily activities (Norasmah \& Shuki, 2009). Multiplication facts is one of the basic skills in mathematics. Syllabus Integrated Primary School Curriculum (KBSR) and Standard Curriculum for Primary Schools (KSSR) mathematics has placed emphasis on fostering an understanding of concepts and skills multiplication facts (Kementerian Pelajaran Malaysia, 2001, 2013). Although the focus of learning multiplication facts in the curriculum, but there are still many students who do not master the multiplication facts well (Steel \& Funnell, 2001; Zainuddin \& Mohd. Rashid, 2007).

Learning multiplication facts is a key issue in mathematics in primary schools (Gardell, 2009). Past research has shown that a lack skill of multiplication facts was the source of low achievement in mathematics (Jennie \& Mohd Johan, 2010; Stanley \& Julaini, 2006; Sharifah et al., 2006; Aida, 2006). This is because most of the questions in the exam requires the application of mathematical multiplication facts skill when answering exam questions. It is difficult for students to solve mathematical problems that may require skill of multiply if they do not mastered the multiplication facts skills. Due to theirs weakness in mastering multiplication facts, they will lose interest, boredom and lack of confidence in learning multiplication facts and so affect their mathematics performance that mostly involve the use of multiplication operations. One of the factors that influence the extent to which the acquisition of students multiplication facts skills is depended on the effectiveness of teaching methods. Accordingly, the method of teaching is one of the important factors that will affects mathematics achievement (Copley, 2000; Hutkemri, 2009).

Therefore, teachers must constantly modify and enrich the range of teaching methods to entice students in improving the learning outcomes. Teaching methods need to be more focused on active participation of students (Effandi, 2003, 2005; Rohana, 2008), the practice of constructivist methods (Charlesworth, 2005) and attracted the attention of students to teaching and learning becomes more meaningful. Through active participation in teaching and learning activities, students will have the opportunity to explore, develop, evaluate and learn by 
constructivism. Ineffective teaching methods will limit the amount of input received by the students lessons and so on will affect their math achievement. Therefore, the Magic Fingers Teaching Method (MFTM) is created by focusing on the active involvement of students in learning multiplication facts.

\section{Statement of Research Problem}

Mathematics achievement of deaf students are still at a low level (Mohd. Hanafi, Norani, \& Safani, 2009; Liong, 2009; Liong, Mohd. Hanafi, \& Mohd. Mokhtar, 2010; Moores, 2001; Bull, Marschark, \& Blatto-Vallee, 2005; Traxler, 2000; Powers, 2003; Maccini \& Gagnon, 2000; Kaili, 2006; Nunes et al., 2009; Nunes \& Moreno, 2002). At the national level, mathematics performance deaf candidates in the Primary School Assessment Test (UPSR) for 2008, 2009 and 2010 was not satisfactory (Lembaga Peperiksaan Malaysia, 2011). Percent above the minimum level grade A, B and C for 2008, 2009 and 2010 respectively only $43.3 \%$ (150 students), 45.8\% (288 students) and 50.6\% (263 students). UPSR mathematics achievement is still at an unsatisfactory level in 2012, 2013 and 2014 (Lembaga Peperiksaan Malaysia, 2015). Despite there was an increasing in percentage for the past in the minimum level of grade $\mathrm{A}, \mathrm{B}$ and $\mathrm{C}$ as a whole, but the percentage is still quite low with a record of $56.2 \%$ (158 students), 54.0\% (174 students) and 48.7\% (208 students) respectively for 2012, 2013 and 2014. Within the six years, the percent above the minimum level was only at the level of grade D, which range from $43.3 \%$ to $56.2 \%$ only. This shows that the level of mathematics achievement of deaf students are located at an alarming rate.

The decline in mathematics achievement for deaf candidates have also been reported in study of Sharifah et al. (2006). The aim of Sharifah et al. study is to review the pattern and distribution of performance on the three main categories of special education candidate of blind, deaf and learning disability those were taking public examinations in the Primary School Assessment Test (UPSR), Lower Secondary Assessment (PMR) and Certificate of Education Malaysia (SPM) for the year 2001 to 2005 for the whole country. The findings were reported majority deaf candidates have obtained $\mathrm{D}$ and $\mathrm{E}$ in mathematics in all three stages of the test. Percentage of passing mathematics UPSR deaf candidates in 2001, 2002, 2004 and 2005 is in the range of 3\% to $44 \%$ which is $2.7 \%$ (53 students) in 2001, 29.2\% (71 students) in 2002, 34.2\% (107 students) in 2004 and $43.5 \%$ (93 students) in 2005.

Hinges on the report and the findings above, the educators in particular must take seriously the occurrence of the problem by finding ways to overcome the problem of mathematical achievement which is still at an unsatisfactory level. Without appropriate action, the problem will not be solved successfully. String, the causes that led to the occurrence of the problems that need to be studied. According to Hyde, Zevenbergen and Power (2003), mathematics achievement is directly related to linguistic proficiency and abilities students in number of operations. One of the skills is multiplication facts. When facing difficulty in memorizing multiplication facts, the student will not be interested and bored to answer questions involving multiplication. Weakness in mastering of multiplication facts is causing them to fail to answer mathematics questions related to basic multiply facts such as questions involving multiplication and division operation. Therefore, the weak in mastering multiplication facts is one of the factors that will lead to low achievement in mathematics. Thus, multiplication facts teaching methods need to be focus in improving student proficiency on the skills.

In teaching and learning multiplication facts at the primary school level, rote methods commonly be used (Norasmah \& Shuki, 2009). Sousa (2006) explains that memorization exercises are activities that aim to remember and store any information or facts to circumstances but do not understand the concept in of long-term memory such as memorizing multiplication facts. This may cause students to feel quickly tired and less motivated to learn multiplication facts because using too much time to memorize the multiplication facts but do not understand (Roslan, 2004; Kamaliah, 2006; Zainudin \& Mohd. Rashidi, 2007). Therefore, deaf students need an appropriate teaching methods with the characteristics of the special needs of their problems (Tucker, Singleton, \& Weaver, 2006; Brahier, 2005).

On the lack of auditory sensory, deaf students often have problems in encoding the input received and processed information (Berk, 2009). Encoding misinformation will shorten the information stored in short-term memory stores. Low memory problems cause they cannot count the number sequence correctly (Sliva, 2004). Hence, method of manipulative "hands on" and an active involvement of students in the teaching and learning activities is necessary to help deaf students in learning multiplication facts. When students do it themselves, then the average rate information storage will be higher. The information can be saved by $75 \%$ after 24 hours compared to other methods that are less participation of students to do such as lectures, reading, audiovisual, demonstrations and group discussions (Sousa, 2006). 
Therefore, the Magic Fingers Teaching Method (MFTM) which focused on manipulative techniques and the active involvement of the students in performing the calculation of the product of the multiplication facts are applicable to deaf students. This is because the lessons that integrate physical and mental reflection are more effective in learning the multiplication facts as a parable told by Marshark, Lang and Albertini (2002), "Tell me, and I will forget; show me, and I will remember; involve me and I will understand".

\section{Research Objectives}

\subsection{The Purpose of the Study}

This study aims to examine the effects of the Magic Fingers Teaching Method (MFTM) on teaching and learning multiplication facts among deaf students and their perception towards MFTM.

\subsection{The Objectives of the Study}

i. Determine whether there is a difference in multiplication facts achievement between students who receive Magic Fingers Teaching Method (MFTM) and Conventional Teaching Methods (CTM).

ii. Reviewing the perception of deaf students towards MFTM.

\subsection{Research Questions}

i. Are there significant differences in the mean scores of multiplication facts achievement among deaf students those received MFTM between pre-test and post-test?

ii. Are there significant differences in the mean scores of multiplication facts achievement among deaf students those received CTM between pre-test and post-test?

iii. Are there significant differences in the mean scores of pre-test multiplication facts achievement among deaf students between group received MFTM and CTM?

iv. Are there significant differences in the mean scores of post-test multiplication facts achievement among deaf students between group received MFTM and CTM?

$v$. What are the perceptions of deaf students towards MFTM?

\subsection{Null Hypothesis}

$\mathrm{H}_{0} 1$ : There are no significant differences in the mean scores of multiplication facts achievement for those students received MFTM between pre-test and post-test.

$\mathrm{H}_{0}$ 2: There are no significant differences in the mean scores of multiplication facts achievement for those students received CTM between pre-test and post-test.

$\mathrm{H}_{0} 3$ : There are no significant differences in the mean scores of pre-test multiplication facts achievement among deaf students between group received MFTM and CTM.

$\mathrm{H}_{0} 4$ : There are no significant differences in the mean scores of post-test multiplication facts achievement among deaf students between group received MFTM and CTM.

\section{Methodology}

This study has a quasi-experimental design with non-equivalent pre-test and post-test control group design which involves testing the hypothesis by using inferential statistics.

Table 1. Research design

\begin{tabular}{cccc}
\hline & Pre-test & Treatment & Post-test \\
\hline Experimental group & $\mathrm{O}$ & $\mathrm{X}_{1}$ & $\mathrm{O}_{1}$ \\
Control group & $\mathrm{O}$ & $\mathrm{X}_{2}$ & $\mathrm{O}_{1}$ \\
\hline
\end{tabular}

Note. $\mathrm{O}=$ Pre-test Experimental Group (EG) / Control Group (CG),

$\mathrm{X}_{1}=$ Treatment with MFTM,

$\mathrm{X}_{2}=$ Treatment with CTM,

$\mathrm{O}_{1}=$ Post-test Experimental Group (EG) / Control Group (CG). 
Pre-test $(\mathrm{O})$ was carried out on both the EG and CG, followed by treatment of the MFTM $\left(\mathrm{X}_{1}\right)$ and CTM $\left(\mathrm{X}_{2}\right)$. After treatments $X_{1}$ and $X_{2}$ were given, respondents from both EG and CG answer the post-test $\left(O_{1}\right)$. Post-test was conducted to see whether there was a difference in multiplication facts achievement before and after the treatment was given. Time allocation for each test was 40 minutes. In context of this study, CTM was an usual teaching method which applied by using chalk and talk, memorization and written notes in teaching multiplication fact, whereas MFTM is created by the researcher (Liong, 2009). MFTM is based on using fingers in learning multiplication fact (Anghileri, 2008; Copley, 2000), active participation involving physical and mental reflection (Bobis, Mulligan, \& Lowrie, 2004), the ideas of Gypsy multiplication of multiplication facts 6 to 8 for the 6th, 7th, 8th and 9th group (Miles, 2004) and finger technique of multiplication fact 9 (Ellis, 2004). Only multiplication fact of 2 to 9 are focused in MFTM.

A total of 70 deaf students, with sensorineural hearing loss in range of profound hearing impaired $90 \mathrm{~dB}$ and above in Years Four, Five and Six within age 10 to 12 years old have been selected randomly from deaf exclusive setting programme in Special Educational School in Selangor and the Federal Territory of Kuala Lumpur for distribution to the experimental group and the control group. Each group has 35 students those divided equally by same age and level of mathematics achievement. Mid-year school mathematics examination results was taken in determining theirs level of achievement. The schools were selected based on having same background criteria such as the size of the school and located at urban area. In addition, screening tests also be done on respondents before the actual study was conducted. They were using sign language total communication as medium communication in school. These efforts were made in aim of forming homogenous groups for both experimental group and control group to fulfil one of the criteria in quasi experiment and enable to produce more accurate results.

In this study, researcher conducted MFTM while CTM was ran by math teacher at the schools. On factors there was no teacher expertise in sign language in an experimental group's school, researcher's experience in teaching mathematics among deaf students for more than ten years, and having academic qualification in deaf special education were the reasons why researcher conducted the MFTM. Despite previous studies that show data obtained will be biased due to researcher's expectations who desire to see the effect on the experimental group, however it would be only applied in certain particular discipline of studies, but not at all disciplines (Cook \& Campbell, 1979). To ensure that the teaching methods used by teachers was purely Conventional Teaching Method (CTM), researcher has briefed to them on the definition of CTM, scopes of multiplication facts that need to be taught, the implementation schedule and the duration of teaching session time before CTM was carried out. In addition, both EG and CG teachers were also required to prepare daily lesson plan for each session in teaching multiplication facts according to the same scopes, schedule and its duration. Malay Sign Language Total Communication were used as medium in delivering the lesson.

In ensuring that teachers have properly conducted MFTM or CTM, a math teacher was asked to monitor during the lesson going on by using a checklist. The checklist contains 16 items that describe the situation or behaviour of teachers when handling teaching sessions. Math teacher who monitors were asked to indicate "yes" or "no" to each item based on the situation or what was done by the teacher. Reviewing on all checklists collected, there was no bias against experimental group or control group. As the contents only covered multiplication fact of two to nine, therefore the period of teaching was two hours which an hour per week. During the tests session, all respondents were in good health and willing to answer tests. Comfortable surroundings without disruption was provided for them too. The pre-test and post-test were analysed using t-test inferential statistics whereas descriptive statistics mean and percentage used in analysing questionnaire.

The instruments were used in this study are pre-test, post-test and questionnaire. Pre-test and post-test contains 61 items multiplication facts which are same but differ in arrangement with the marks awarded for each item correctly answered. The questionnaire consists of 20 items for which the maximum score is 100 and the minimum score is 20. A total of four sub dimensions of interest to MFTM, self-confidence, persistence and motivation were measured using a five-level Likert scale of 1 to 5 as below.

Table 2. Measurement scale questionnaire

\begin{tabular}{cccccc}
\hline Level & Strongly disagree & Disagree & Uncertain & Agree & Strongly agree \\
\hline Score & 1 & 2 & 3 & 4 & 5 \\
\hline
\end{tabular}


The purpose of the questionnaire was to review the students' perceptions towards MFTM. The pre-test, post-test and questionnaire were developed by the researcher, the validity and reliability of the instruments have been identified. The coefficient of reliability for the pre-test, post-test and the questionnaire was high. Pre-test and post-test reliability coefficient Kuder Richardson (KR) 20 is 0.9793 , while questionnaire has the overall Cronbach Alpha 0.941 which consisted with 0.878 in interest to MFTM dimension, 0.842 in dimension of self-confidence, 0.803 in persistence dimensions and 0.802 in dimension of motivation.

\section{Results and Discussion}

To answer the first research objectives, hypothesis testing $\mathrm{H}_{0} 1, \mathrm{H}_{0} 2, \mathrm{H}_{0} 3$, and $\mathrm{H}_{0} 4$ was tested through $\mathrm{t}$ test while descriptive statistics mean and percentage was used to answer the second research objectives.

\subsection{The Effectiveness of Magic Fingers Teaching Method (MFTM) and Conventional Teaching Methods (CTM) in Multiplication Facts Achievement among Deaf Student}

First research question: Are there significant differences in the mean scores of multiplication facts achievement among deaf students those received MFTM between pre-test and post-test?

$\mathrm{H}_{0} 1$ : There are no significant differences in the mean scores of multiplication facts achievement for those students received MFTM between pre-test and post-test.

Table 3. Pre-test and post-test analysis for experimental group

\begin{tabular}{llllll}
\hline Test & Number of respondents & Mean & s.d. & t value & Significant \\
\hline Pre-test & 35 & 29.86 & 21.80 & 4.793 & $0.001^{*}$ \\
Post-test & 35 & 40.00 & 19.60 & & \\
\hline
\end{tabular}

$* \mathrm{p}<0.05$.

s.d.: Standard deviation.

Results showed $\mathrm{H}_{0} 1$ was rejected at the significant level of $0.05(\mathrm{t}=4.793, \mathrm{df}=68, \mathrm{p}<0.05, \mathrm{n}=35)$. This means that there are significant differences in the mean score of multiplication facts achievement for those students received MFTM between the pre-test $($ mean $=29.86$, s.d. $=21.80)$ and post-test $($ mean $=40.00$, s.d. $=19.60)$.

Second research question: are there significant differences in the mean scores of multiplication facts achievement among deaf students those received CTM between pre-test and post-test?

$\mathrm{H}_{0} 2$ : There are no significant differences in the mean scores of multiplication facts achievement for those students received CTM between pre-test and post-test.

Table 4. Pre-test and post-test analysis for control group

\begin{tabular}{lccccl}
\hline Test & Number of respondents & Mean & s.d. & t value & Significant \\
\hline Pre-test & 35 & 29.09 & 20.11 & -1.367 & 0.180 \\
Post-test & 35 & 30.57 & 19.21 & & \\
\hline
\end{tabular}

s.d.: Standard deviation.

Results showed $\mathrm{H}_{0} 2$ was received at significant level $0.05(\mathrm{t}=-1.367, \mathrm{df}=68, \mathrm{p}>0.05, \mathrm{n}=35)$. This means there is no significant difference between the mean score of multiplication facts achievement for those students received CTM between the pre-test $($ mean $=29.09$, s.d. $=20.11)$ and post-test $($ mean $=30.57$, s.d. $=19.21)$.

Third research question: Are there significant differences in the mean scores of pre-test multiplication facts achievement among deaf students between group received MFTM and CTM?

$\mathrm{H}_{0} 3$ : There are no significant differences in the mean scores of pre-test multiplication facts achievement among deaf students between group received MFTM and CTM. 
Table 5. Pre-test analysis for experimental group and control group

\begin{tabular}{lccccc}
\hline Group & Number of respondents & Mean & s.d. & t value & Significant \\
\hline Experimental & 35 & 29.86 & 21.80 & 0.154 & 0.878 \\
Control & 35 & 29.09 & 20.11 & & \\
\hline
\end{tabular}

s.d.: Standard deviation.

Table 5 above shows $\mathrm{H}_{0} 3$ was received at the significant level of 0.05 . Results showed that the mean score of pre-test between experimental group and control group is not significant $(t=0.154, \mathrm{df}=68, \mathrm{p}>0.05)$. This means there are no differences between mean score of pre-test between group received MFTM (mean $=29.86$, s.d. $=21.80, \mathrm{n}=35)$ and group received CTM $($ mean $=29.09$, s.d. $=20.11, \mathrm{n}=35)$.

The fourth research question: are there significant differences in the mean scores of post-test multiplication facts achievement among deaf students between group received MFTM and CTM?

$\mathrm{H}_{0} 4$ : There are no significant differences in the mean scores of post-test multiplication facts achievement among deaf students between group received MFTM and CTM.

Table 6. Post-test analysis for experimental group and control group

\begin{tabular}{cccccc}
\hline Test & Number of respondents & Mean & s.d. & t value & Significant \\
\hline Experimental & 35 & 40.00 & 19.60 & 2.032 & $0.046^{*}$ \\
Control & 35 & 30.57 & 19.21 & & \\
\hline
\end{tabular}

$* \mathrm{p}<0.05$.

Table 6 above shows $\mathrm{H}_{0} 4$ was rejected at the significant level of 0.05 . Results showed that the mean scores of post-test between experimental group and control group was significant $(\mathrm{t}=2.032, \mathrm{df}=68, \mathrm{p} \leq 0.05, \mathrm{~N}=70)$. This means there are difference mean scores between group received MFTM (mean $=40.00$, s.d. $=19.60, \mathrm{n}=35$ ) and group received CTM (mean $=30.57$, s.d. $=19.21, \mathrm{n}=35)$ in the post-test.

The findings of the pre-test analysis of the experimental group and the control group (Table 5) shows the selected respondents to both the experimental and control groups were homogeneous, which gives the meaning that the findings are legitimate and quasi-experimental control criteria have been fulfilled. MFTM has a significant positive impact on the multiplication facts achievement (Table 3 and Table 6), but CTM does not have a significant impact in multiplication facts achievement (Table 4). This clearly shows that the MFTM is suitable for application to the deaf students.

In terms of basic features, MFTM has met the characteristics of their special needs, namely the use of fingers and labelling is the same number of fingers in sign language for deaf students. For example, in the second part of the MFTM, each finger will be labelled with a specific numerical value like number 6 on the little finger, number 7 on the ring finger, number 8 on middle finger, number 9 on the index finger and number 10 on thumb. Therefore, MFTM that combines the use of fingers in learning multiplication facts (Anghileri, 2008; Copley, 2000), as well as the active involvement of physical and mental reflection (Bobis et al., 2004), Gypsy ideas that involve learning multiplication facts 6 to 8 for the 6th, 7th, 8th and 9th such as 6x6, 7x6, 8x6 and 9x6 (Miles, 2004) and finger technique of 9 (Ellis, 2004) is very suitable in giving new experiences to students directly in learning multiplication facts. The method of multiplication using fingers as a reasonable method disclosed to the students because that method has involved component of visual perception, physical movement and active involvement of students through their own experience simultaneously in the learning process that will produce a teaching and learning are more productive (Wee, 2010).

Past research has shown the ability of arithmetic operations is depend on a person's working memory system or purporting capacity of memory (Davis \& Kelly, 2003; Lee, Kyoung-Min, \& Kang So-Young, 2002). Multiplication fact skill is one of the abilities in arithmetic operations. Low memory will prevent the processing of arithmetic operations. Although capacity of memory for deaf students is lower on resistance factors auditory sensory problems (Berk, 2009), but their multiplication facts achievement is much better by practicing MFTM. This may be due to the use of manipulative "hands on" in MFTM. By using their fingers as the manipulation of 
physical materials, they will able to get the answers easily because according to Anghileri (2008) and Copley (2000), fingers counting is an effective way in searching the answers of multiplication facts. Thus, MFTM is a good alternative in learning multiplication facts and is suitable for deaf students.

The results showed CTM is less effectively used in learning multiplication facts. This show teaching method is important in performing better quality output lessons. Such findings Lee and Sharifah (2005) have analysed 73 studies conducted in mathematics education from 1972 to 2000 showed that effective teaching methods will increase the interest of students in learning mathematics. High interest will further encourage student learning. The process learning in CTM is just like drilling without understanding the concept. Thus, the student's interest and enthuse in learning multiplication facts will also be reduced. The Study of Zainudin and Mohd. Rashidi (2007) have shown the rate of improvement in the performance of multiplication facts is that students receive the CTM through the rote method is one-fold lower than the Plot Method among students primary school. CTM also less effective in teaching that involving mathematical thinking and problem solving (Jones \& Southern, 2003). In MFTM, students will be easier to remember and not face many problems especially when studying the second part of MFTM by using fingers as a basis for calculation multiplication facts answer.

\subsection{The Perceptions of Deaf Student towards MFTM}

The level of deaf students' perceptions towards MFTM as a whole is higher (mean $=75.63$, s.d. $=10.38$ ) namely the interest towards MFTM $($ mean $=23.14$, s.d. $=3.26)$, self-confidence $($ mean $=22.71$, s.d. $=3.49)$, persistence $($ mean $=15.14$, s.d. $=2.68)$ and motivation $($ mean $=14.63$, s.d. $=3.14)$ as shown in Table 7 below.

Table 7. Distribution of mean and standard deviation MFTM

\begin{tabular}{llll}
\hline Dimension & Mean & Standard deviation & Level \\
\hline Interest towards MFTM & 23.14 & 3.26 & High \\
Self-Confidence & 22.71 & 3.49 & High \\
Persistence & 15.14 & 2.68 & High \\
Motivation & 14.63 & 3.14 & High \\
Whole & 75.63 & 10.38 & High \\
\hline
\end{tabular}

A total of six items are in the dimension of interest to MFTM. Students show high interest towards MFTM which consisted item of "high interest in learning MFTM" (mean $=4.09$, s.d. $=0.85$ ), "it is fun when learning MFTM" $($ mean $=4.03$, s.d. = 0.79), "like to learn MFTM" $($ mean $=4.03$, s.d. $=1.01)$ and "the steps in MFTM are easy to follow" (mean $=3.89$, s.d. $=0.80)$ while the other two items have a moderate level namely "MFTM is interesting" ( mean $=3.54$, s.d. $=1.12)$ and "effective" $($ mean $=3.57$, s.d. $=1.24)$ in searching multiplication facts answers. Past studies have also shown that finger method has positive effects in terms of the level of interest and involvement of respondents to the learning activities (Mohd. Fairuz \& Mohammad Zailani, 2010; Kueh, 2010). The research of Iskandar and Asbullah (2010) found that students would prefer that method because it does not require a lot of material and high cost. They just only use their mind and fingers. By having criteria of interests, having fun, a high level of involvement and the MFTM's steps are easy to follow will motivate students in learning and mastering multiplication facts.

The findings showed MFTM has given a high level of self-confidence to the students in mastering multiplication facts in terms of "knowing how to get the multiplication facts answer" (mean $=4.06$, s.d. $=1.06$ ), "can answer multiplication facts from two to nine with confidence" (mean $=3.83$, s.d. $=1.29)$, "can get multiplication facts answers quickly" (mean $=3.91$, s.d. $=1.04$ ) and "using the MFTM as the main method in finding multiplication facts answers" (mean $=3.83$, s.d. =1.05). The others two items are at a moderate level, namely "more adept in multiplication facts" $($ mean $=3.49$, s.d. $=1.07)$ and "more easily to find the answer" $($ mean $=3.60$, s.d. $=1.09)$. Result also found that students have demonstrated a high level of persistence in learning multiplication facts such as "be more diligent in studying multiplication facts" ( mean $=4.23$, s.d. $=0.97)$ and "spend more time to learn the multiplication facts" ( mean $=3.74$, s.d. $=1.17)$, whereas at moderate level "in learning multiplication facts with vigorously" (mean $=3.60$, s.d. $=1.26$ ) and "more fun to learn the multiplication facts" (mean $=3.57$, s.d. = 1.14). The study also showed that student's motivation in learning multiplication facts after receiving MFTM is at high level such as "students are more interested to learn multiplication facts" (mean $=3.74$, s.d. = 1.07), "more eager to learn the multiplication facts" (mean $=3.74$, s.d. $=1.17)$ and "always take an initiative to 
learn the multiplication facts" (mean $=3.69$, s.d. $=1.30)$, and item "multiplication facts are easy to learn" is at a moderate level $($ mean $=3.46$, s.d. $=1.42)$.

This study shows that there is a positive attitude in term of persistence and motivation in multiplication facts learning after MFTM is taught. Study of Ting (2010) also reported that the fingers method has attract students in finding multiplication facts answers and changing them to positive attitude towards mathematics. Students who have positive attitude towards mathematics will have higher math achievement (Mullis et al., 2008). According to Moores (2001), the level of achievement is closely related to the time allotted for learning the subject. As in this study, students were found to have mean score at a high level in the item "after studying the MFTM, I will spend more time to learn the multiplication facts" that are contained in the dimension of persistence. Students will be able to enhance the proficiency of the multiplication facts through a period of extra time spent. Thus, the implementation of MFTM is able to help student to get higher multiplication facts achievement. The perception of student towards MFTM that will determine the level of desire or her attitude in practicing the method in learning multiplication facts. According Marshark et al. (2002), perception is a factor that encourages student to learn mathematics. Thus, with a good perception to MFTM will encourage student to learn multiplication facts.

The research of Mohd. Hanafi (2005) found that the main stumbling block to the achievement of deaf students is a lack of motivation and low self-confidence. However, MFTM succeed to motivate and enhance students' self-confidence in learning multiplication facts. The findings also indicate that they are more motivated in term of interested, enthusiastic and initiative to learn multiplication facts. Students also showed self-confidence in answering multiplication facts from two to nine with confidence, get answers quickly and use MFTM as the main method in finding multiplication facts answers. Thus, MFTM is suitable to practice in teaching and learning multiplication facts especially for those deaf students.

\section{Conclusion}

This study examined the effectiveness of MFTM using a quasi experimental design. MFTM is a method which is based on the use of fingers, the active involvement of students, mental reactions and physical reflection. Besides, students' perceptions of the MFTM also reviewed. The instruments are pre-test, post-test and questionnaire. A total of 70 deaf students were selected as respondents. The study found MFTM is effective in learning multiplication facts. Students have given the high perception in terms of interest in the MFTM, self-confidence, persistence and motivation in learning multiplication facts. Thus, MFTM should be practiced widely in schools.

These findings have implications for students, parents, teachers, the Division of Special Education, the Ministry of Education and other researchers from aspects such as readiness, planning and implementation of teaching and learning multiplication facts. The level of parental involvement and commitment should be enhanced in order to improve their child's multiplication facts achievement. Teachers need to apply various of teaching methods that are student-centered. In addition, teachers should own knowledge of pedagogy, contents and math assessments. The Division of Special Education should come forward to propose all the problems and needs of deaf students such as curriculum modifications that is consistent with their limitations of the auditory sensory. This action is necessary in increasing mathematics achievement of deaf students.

\section{References}

Aida, I. (2006). Meningkatkan kemahiran murid mencongak fakta asas darab melalui pendekatan permainan domino. Jurnal Kajian Tindakan Negeri Johor, 2006, 1-13.

Anghileri, J. (2008). Uses of counting in multiplication and division. In I. Thompson (Ed.), Teaching And Learning Early Number (2nd ed., pp. 110-121). England: Open University Press.

Berk, L. E. (2009). Child developing (8th ed.). Boston: Pearson International Edition.

Bobis, J., Mulligan, J., \& Lowrie, T. (2004). Mathematics for children: Challenging children to think mathematically (2nd ed.). Australia: Pearson Prentice Hall.

Brahier, D. J. (2005). Teaching secondary and middle school mathematics (2nd ed.). Boston: Pearson Education.

Bull, R., Marschark, M., \& Blatto-Vallee, G. (2005). SNARC hunting: Examining number representation in deaf students. Learning and Individual Differences, 15, 223-236. http://dx.doi.org/10.1016/j.lindif.2005.01.004

Charlesworth, R. (2005). Experiences in math for young children (5th ed.). Australia: Thomson Delmar Learning.

Cook, T., \& Campbell, D. T. (1979). Quasi-experimentation: Design and analysis issues for field settings. Boston: Houghton Mifflin Company. 
Copley, J. V. (2000). The young child and mathematics. Washington: National Association for the Education of Young Children.

Davis, S. M., \& Kelly, R. R. (2003). Comparing deaf and hearing college students' mental arithmetic calculations under two interference conditions. American Annals of the Deaf, 48(3), 213-221. http://dx.doi.org/10.1353/aad.2003.0018

Effandi, Z. (2003). Kesan pembelajaran koperatif ke atas pelajar-pelajar dalam kelas matematik matrikulasi (Unpublished doctoral dissertation). Fakulti Pendidikan, Universiti Kebangsaan Malaysia.

Effandi, Z. (2005). Asas pembelajaran koperatif dalam matematik. Shah Alam: Karisma Publications Sdn. Bhd.

Ellis, S. A. T. (2004). Steering a way through number facts. In T. R. Miles, \& E. Miles (Eds.), Dyslexia and mathematics (2nd ed., pp. 120-138). London: Routledge Falmer.

Gardella, F.J. (2009). Introducing difficult mathematics topic in the elementary classroom: A teacher's guide to initial lessons. New York: Routledge Taylor \& Francis Group.

Hutkemri. (2009). Keberkesanan strategi pemetaan informasi ke atas pengetahuan konseptual matematik pelajar sekolah menengah pertama (SMP) (Unpublished master's thesis). Fakulti Pendidikan, Universiti Kebangsaan Malaysia.

Hyde, M., Zevenbergen, R., \& Power, D. (2003). Deaf and hard of hearing students' solving of arithmetic word problems. American Annals of the Deaf, 148, 56-64. http://dx.doi.org/10.1353/aad.2003.0003

Iskandar, S. I., \& Asbullah, B. (2010). Penggunaan jari jemari untuk memudahkan murid-murid tahun 4 menghafal sifir 9. In Prosiding seminar penyelidikan tindakan (matematik pendidikan rendah) Jabatan Matematik Institut Pendidikan Guru Kampus Sarawak (pp. 134-142).

Jennie, L. L., \& Mohd Johan, J. (2010). Penggunaan bahan manipulatif (bekas telur) untuk membantu murid tahun tiga dalam memahami sifir enam. In Prosiding seminar penyelidikan tindakan (matematik pendidikan rendah) Jabatan Matematik Institut Pendidikan Guru Kampus Sarawak (pp. 125-133).

Jones, E. D., \& Southern, W. T. (2003). Balancing perspectives on mathematics instruction. Focus on Exceptional Children, 35(9), 1-16.

Kaili, C. (2006). Math in motion: Origami math for students who are deaf and hard of hearing. Journal of Deaf Studies and Deaf Education, 11(2), 262-266.

Kamaliah, A. A. (2006). Penggunaan rangsangan muzik terhadap penguasaan sifir murid-murid di Sekolah Menengah Kebangsaan Sultanomar, Dungun (Unpublished bachelor's thesis). Fakulti Pendidikan, Universiti Teknologi Malaysia.

Kementerian Pelajaran Malaysia. (2001). Sukatan Pelajaran Matematik Kurikulum Bersepadu Sekolah Rendah. Pusat Perkembangan Kurikulum Kementerian Pelajaran Malaysia.

Kementerian Pelajaran Malaysia. (2013). Kurikulum Standard Sekolah Rendah Matematik Tahun Empat: Dokumen Standard Kurikulum Dan Pentaksiran (Draf Edition). Bahagian Pembangunan Kurikulum Kementerian Pelajaran Malaysia.

Kueh, S. S. (2010). Use of finger method in learning multiplication among primary three pupils. Koleksi Artikel Penyelidikan Tindakan, Seminar Penyelidikan Tindakan Tahun 2010.

Lee, K. M., \& Kang, S. Y. (2002). Arithmetic operation and working memory: Differential suppression an dual tasks. Cognition, 83, 63-68. http://dx.doi.org/10.1016/S0010-0277(02)00010-0

Lee, S. E., \& Sharifah, N. A. S. Z. (2005). Studies of mathematics education at the faculty of education, University of Malaya: Focus and direction. Journal Pendidikan Universiti Malaya, 3(1), 7-28.

Lembaga Peperiksaan Malaysia. (2011). Analisis prestasi matematik calon normal dan pekak peringkat nasional UPSR dan PMR 2008-2010.

Lembaga Peperiksaan Malaysia. (2015). Analisis prestasi matematik murid arus perdana dan murid bermasalah pendengaran UPSR 2012-2014.

Liong, K. T. (2009). Gerakan jari-jemari dalam membantu penguasaan sifir pelajar-pelajar bermasalah pendengaran aliran kemahiran. Kajian Tindakan. Keningau: Sekolah Menengah Teknik Keningau Sabah. 
Liong, K. T., Mohd. Hanafi, M. Y., \& Mohd. Mokhtar, T. (2010). Kaedah Jemari Ajaib dalam pengajaran dan pembelajaran sifir pelajar bermasalah pendengaran. In Proceedings First Annual Inclusive Education Practices Conference (pp. 86-100).

Maccini, P., \& Gagnon, J. C. (2000). Best practices for teaching mathematics to secondary students with special needs. Focus Exceptional Children, 32(5), 1-22.

Marshark, M., Lang, H. G., \& Albertini, J. A. (2002). Educating deaf students: From research to practice. New York: Oxford University Press.

Miles, T. R. (2004). Theoretical background. In T. R. Miles, \& E. Miles (Eds.), Dyslexia and mathematics (2nd ed., pp. 1-20). London: Routledge Falmer.

Mohd. Fairuz, D., \& Mohammad Zailani, J. (2010). Membantu murid tahun tiga meningkatkan kemahiran mendarab sifir 6, 7, 8 dan 9 dengan menggunakan jari. In Prosiding seminar penyelidikan tindakan (matematik pendidikan rendah) Jabatan Matematik Institut Pendidikan Guru Kampus Sarawak (pp. 65-73).

Mohd. Hanafi, M. Y. (2005). Perbandingan pencapaian pelajar pendidikan khas (pekak) menggunakan tiga format peperiksaan Ujian Penilaian Sekolah Rendah (UPSR) (Unpublished doctoral dissertation). Fakulti Pendidikan, Universiti Kebangsaan Malaysia.

Mohd. Hanafi, M. Y., Norani, S., \& Safani, B. (2009). Prestasi akademik pelajar pekak. In M. J. Zalizan (Ed.), Pendidikan kanak-kanak berkeperluan khas: Konsep dan amalan (pp. 198-225). Bangi: Universiti Kebangsaan Malaysia.

Moores, D. F. (2001). Educating the deaf: Psychology, principles and practices (5th ed.). Boston: Houghton Mifflin Company.

Mullis, I. V. S. et al. (2008). TIMSS 2007 International mathematics report: Findings from IEA's Trends in International Mathematics and Science study at the fourth and eighth grades. Chestnut Hill, MA: TIMSS \& PIRLS International Study Center, Boston College.

Norasmah, O., \& Shuki, O. (2009). Kaedah pengajaran dan pembelajaran. In I. Noraini, \& O. Shuki (Eds.), Pengajaran dan pembelajaran: teori dan praktis (pp. 75-100). Bangi: Universiti Kebangsaan Malaysia.

Nunes, T., Bryant, P., Burman, D., Bell, D., Evans, D., \& Hallett, D. (2009). Deaf children's informal knowledge of multiplicative reasoning. Journal of Deaf Studies and Deaf Education, 14(2), 260-277. http://dx.doi.org/10.1093/deafed/enn040

Nunes, T., \& Moreno, C. (2002). An intervention program for promoting deaf pupils' achievement in mathematics. Journal of Deaf Studies and Deaf Education, 7(2), 120-133. http://dx.doi.org/10.1093/deafed/7.2.120

Powers, S. (2003). Influences of student and family factors on academic outcome of mainstream secondary school deaf students. Journal of Deaf Studies and Deaf Education, 8(1), 57-78. http://dx.doi.org/10.1093/deafed/8.1.57

Rohana, A. T. (2008). Pembelajaran berasaskan masalah matematik. In S. M. Y. Aida, F. M. A. Ahmad, \& T. Othman (Eds.), Amalan dalam pengajaran dan pembelajaran: Sains, matematik dan pembelajaran berasaskan ICT (pp. 44-56). Serdang: Penerbit Universiti Putra Malaysia.

Roslan, J. (2004). Penguasaan sifir di kalangan murid tahun 4 di sekolah-sekolah Zon Keramat, Kuala Lumpur (Unpublished bachelor's thesis). Universiti Pendidikan Sultan Idris.

Sharifah, M. N., Habibah, E., Rahil, M., Rohani, A. T., Samsilah, R., \& Tajularipin, S. (2006). Laporan akhir kajian ciri-ciri sekolah dan pelajar berkeperluan khas yang berkaitan dengan pencapaian peperiksaan UPSR, PMR dan SPM. Laporan yang dibiayai oleh Jabatan Pendidikan Khas Kementerian Pelajaran Malaysia, Fakulti Pengajian Pendidikan Universiti Putra Malaysia.

Sliva, J. A. (2004). Teaching inclusive mathematics to special learners K-6. California: Corwin Press Inc.

Sousa, D. A. (2006). How the brain learns (3rd ed.). California: A Sage Publications Company.

Stanley, G. J., \& Julaini, J. M. (2006). Masalah penguasaan asas darab di dua buah sekolah rendah dalam bahagian Sarikel. Seminar Penyelidikan Pendidikan, Sarawak: Institut perguruan Rajang Bintagor.

Steel, S., \& Funnell, E. (2001). Learning multiplication facts: A study of children taught by discovery methods in England. Journal of Experimental Child Psychology, 79, 37-55. http://dx.doi.org/10.1006/jecp.2000.2579 
Stewart, D. A., \& Kluwin, T. N. (2001). Teaching deaf and hard of hearing students: Content, strategies and curriculum. Boston: Allyn and Bacon.

Ting, W. U. (2010). The effect of finger method in improving Primary four pupils' multiplication skills. Koleksi Artikel Penyelidikan Tindakan, Seminar Penyelidikan Tindakan Tahun 2010, IPG Kampus Batu Lintang (Matematik Pendidikan Rendah), Sarawak.

Traxler, C. B. (2000). The Stanford Achievement Test, $9^{\text {th }}$ edition: National norming and performance standards for deaf and hard of hearing students. Journal of Deaf Studies and Deaf Education, 5(4), 337-348. http://dx.doi.org/10.1093/deafed/5.4.337

Tucker, B. F., Singleton, A. H., \& Weaver, T. L. (2006). Teaching mathematics to all children: Designing and adapting instruction to meet the needs of diverse learners (2nd ed.). New Jersey: Pearson Merill Prentice Hall.

Wee, R. C. L. (2010). The effect of finger method in improving primary four pupils' multiplication skills. Koleksi Artikel Penyelidikan Tindakan, Seminar Penyelidikan Tindakan Tahun 2010, IPG Kampus Batu Lintang (Matematik Pendidikan Rendah), Sarawak, IPG Kampus Batu Lintang Sarawak.

Zainudin, A. B., \& Mohd. Rashidi, M. J. (2007). Kaedah petak sifir: Kajian perbandingan matematik tahun 4 dalam penguasaan fakta asas darab. Journal Pendidikan Universiti Teknologi Malaysia, 12, 91-98.

\section{Copyrights}

Copyright for this article is retained by the author(s), with first publication rights granted to the journal.

This is an open-access article distributed under the terms and conditions of the Creative Commons Attribution license (http://creativecommons.org/licenses/by/3.0/). 